\title{
The Semantics of Color: Reply to Response to Review
}

\author{
Raymond Pierotti ${ }^{1^{*}}$ \\ ${ }^{1}$ Department of Ecology and Evolutionary Biology, University of Kansas, Lawrence, USA. \\ pierotti@ku.edu
}

Received May 27, 2021

Accepted June 28, 2021

Published August 5, 2021

OPEN ӘACCESS

DOI 10.14237/ebl.12.1.2021.1780

Copyright (c) 2021 by the author(s); licensee Society of Ethnobiology. This is an open-access article distributed under the terms of the Creative Commons Attribution-NonCommercial 4.0 International Public License (https://creativecommons.org/licenses/by-nc/4.0), which permits non-commercial use, distribution, and reproduction in any medium, provided the original author and source are credited.

REPLYING TO Albuquerque et al. Ethnobiology Letters 12, https://doi.org/10.14237/ebl.12.1.2021.1763 (2021)

There are a multitude of issues involved in this situation I have found myself drawn into, all of which seem to involve semantics. First, how scholars from different cultural traditions choose to refer to colleagues and their identities. Second, which emerges from the first, is how scholars try to evaluate professional work produced by individuals forced to publish in languages in which they are not fluent. Third, and most scholarly, but in some ways the easiest to address is, "what does it mean to describe the field in which you do research as evolutionary?"

I address these to provide clarity. In the United States, I am considered to be a scholar of color. This is a clumsy, not very useful term; however, in a society as racially confused as twenty-first century America, this term has become a signifier for scholars who do not personally identify as white, Caucasian, or being of European ancestry. This is not intended to be an insult, but an acknowledgment that the individual is trying to exemplify or represent a point of view that comes from outside the dominant culture, which is how I use it.

The category into which I fall can best be described as mixed-blood, which indicates that a person has ancestors that emerged from different cultural ancestries, at least one of which did not come from Western Europe, and is often used to describe people that have some ancestry from Indigenous America (Owens 1998).

Both the United States and Brazil, as American nation states, are colonialist in origin. Their founding involved slavery and genocide, perpetuated by people of Western European ancestry. Today, this means that racism and discrimination are often rampant. Individuals whose ancestor(s) have been victims of Western European invasion and colonialism struggle to define themselves, and how they fit into societies dominated by people considered to be white. I am embarrassed and chagrined to find myself in a situation where I am being identified as "racist and xenophobic" (Albuquerque et al. 2021), and I feel badly that people may have been offended by my neutral terminology.

In 2016, I volunteered to review a book, Evolutionary Ethnobiology, (Albuquerque et al. 2015). As stated previously, "it was with considerable excitement that I initially received this book" (Pierotti 2018:266). Reading this book, I recognized issues that needed to be addressed, involving the second and third issues mentioned above, and that I could not write an honest and positive review (the first issue was never a factor in my review). I communicated this to the book review editor at Ethnobiology Letters, stating that I no longer wished to write a review. The editor said they still wanted the review, even if negative. I submitted a review, that in my concluding paragraph, attempted to find something positive to say, so I naively made statements concerning the ethnicity of many of the authors in this book, not realizing that terminology used routinely in the United States might offend Brazilians, where individuals of European ancestry would take offense at being referred to as scholars of color, or apparently even as "scholars from Latin America," a term that says nothing about ethnicity. 
Albuquerque et al. (2021:80) chose to regard this attempt "as profoundly racist and derogatory..., not only among "non-white" colleagues but also among many colleagues who could be classified as "white." In this sense, we received this term as a racist offense." I feel badly that they were offended; however, in the United States, scholars like myself who do not regard themselves as white have learned to live with the term of color, even if they are phenotypically white. Learning of possible offense in 2019, I agreed with the editors to remove the term from my published review, because I did not want to cause offense, and provided alternative wording. For unknown reasons, this action was not taken by the editors. Two years later, this issue still festers. I apologize for not being more emphatic in making the change.

Concerning publishing in languages other than mother tongue, I am sympathetic and have reviewed numerous manuscripts for journals where I spent considerable effort making sure that the actual statements of the authors were represented accurately in English. I do not know why the editors of Evolutionary Ethnobiology did not make a similar effort to ensure that their intended meanings were accurately presented. My review stated, "I do not really blame the authors, but I am surprised at the lack of basic editing and proofreading, which leaves the authors looking less capable than they surely are" (Pierotti 2018:266). Although I did not say so in my review, I think the editors and especially the publisher (Springer) bears this responsibility. Evolutionary Ethnobiology was rushed into publication without concern about how the authors were presenting themselves. This is a shame, but the people responsible must accept responsibility.

Instead of accepting responsibility, however, Albuquerque et al. (2021:79-80) state that I "chose to focus on minor misuses of words that did not hamper the book's main message nor bring into question the scientific skills of its authors." This is untrue; examples I cited rendered entire sentences and paragraphs incomprehensible. Some chapters featured multiple errors per page, and figure captions and figures were confusing and hard to understand. A couple of errors is 'minor'. Hundreds of errors constitute carelessness. I stand by my comments.

Finally, there exists a question of whether Evolutionary Ethnobiology as written, actually deals with biological evolution in any meaningful way.
The term evolutionary biology is used repeatedly in their publications, but they admit that "the book's content focused on human behavior and cognition in interactions with the environment" (Albuquerque et al. 2021:80). This focus involves psychology rather than evolutionary biology, and should be identified as such (e.g., Ludwig 2018). As stated in my review (Pierotti 2018:266),

This book is promoted by Springer as "the first comprehensive book about evolutionary ethnobiology written in English;" the accuracy of this statement depends on how one defines 'evolutionary' in an ethnobiological context, especially if biological and cultural evolution are conflated to the degree that they are in this book (emphasis added).

Cultural evolution is important in anthropology. Its importance in evolutionary biology, however, is based largely on its existence in nonhumans (de Waal 2001). It is also indirectly important in niche construction. In Evolutionary Ethnobiology, the editors paraphrase Gene Anderson (2011:1) (2) that ethnobiology is "the study of the biological knowledge about certain groups of plants and animals and their interrelationships" (Albuquerque et al. 2015:2), yet they omit animals or even free-living plants. Domestication can involve evolution, but it operates primarily in the realm of artificial rather than natural selection.

To conclude, I also "advocate that future reviews in our study area, and other areas, should be based on respect" (Albuquerque et al. 2021:79). Respect is a two-way street; authors, editors, and publishers also must respect the process of scholarship and present their work in as professional a manner as possible. Albuquerque et al. (2021:81) further states,

We read this as Pierotti setting up a clear dichotomy in which there is an implied 'they,' referring to Latin American authors who have produced low quality material though it is good to see something written by them, and an implied "we" making an argument from an authoritative viewpoint that is North American and anglophone.

They are entitled to their reading, after all we live in a postmodern world. There is no implied 'we' or 'they'; I admit to being a North American anglophone, but I certainly do not regard that as indicative of any inherent superiority. 


\section{References Cited}

Ainana L. I., and I. Zagrebin. 2014. Edible Plants Used by Siberian Yupik Eskimos of Southeastern Chukotka Peninsula, Russia. National Park Service, Shared Beringian Heritage Program, Anchorage, AK.

Albuquerque, U. P., P. M. Medeiros, and A. Casas, eds. 2015. Evolutionary Ethnobiology. Springer International Publishing, Cham, Switzerland.

Albuquerque, U. P., W. S. Ferreira Júnior, I. Vandebroek, R. W. Bussmann, N. Y. PaniaguaZambrana, A. H. Ladio, R. Voeks, F. Melo, M. C. M. Jacob, T. Gonçalves-Souza, A. V. Lopes, and G. T. Soldati. 2021. Decolonizing Latin American Science. Ethnobiology Letters 12:79-81. DOI:10.1423 7/ebl.12.1.2021.1763.

Anderson, E. N. 2011. Ethnobiology: Overview of a Growing Field. In Ethnobiology, edited by E. N. Anderson, D. Pearsall, E. Hunn, and N. Turner. Wiley-Blackwell, Hoboken, NJ.de Waal, F. B. 2001. The Ape and the Sushi Master. Basic Books, New York.
Ludwig, D. 2018. Does Cognition Still Matter in Ethnobiology? Ethnobiology Letters 9:269-275. DOI: 10.14237/ebl.9.2.2018.1350.

Owens, L. 1998. Mixedblood Messages: Literature, Film, Family, Place. University of Oklahoma Press, Norman, OK.

Pierotti, R. 2018. Evolutionary Ethnobiology. Edited by Ulysses Paulino Albuquerque, Patricia Muniz de Medeiros, and Alejandro Casas. 2015. Springer International Publishing, Cham. 197 pp. Ethnobiology Letters 9:266-268. DOI:10.14237/ebl.9.2.2018.1381. 